


\title{
BIOSYNTHESIS AND CHARACTERISTICS OF METABOLITES OF Rhodococcus erythropolis AU-1 STRAIN
}

\section{Ihor Semeniuk ${ }^{l}$, Natalya Koretska ${ }^{1 *}$, Viktoria Kochubei ${ }^{2}$, Victor Lysyak ${ }^{l}$, Tetyana Pokynbroda ${ }^{l}$,Elena Karpenko ${ }^{l}$, Halyna Midyana ${ }^{l}$}

\section{$\operatorname{Address}(e s)$ :}

${ }^{1}$ Department of Physical Chemistry of Fossil Fuels of the Institute of Physical-Organic Chemistry and Coal Chemistry named after L. M. Lytvynenko of the National Academy of Sciences of Ukraine, Str. Naukova, 3a, Lviv, Ukraine, 79060.

${ }^{2}$ National University "Lviv Polytechnic", 3/4 St. George Square, Lviv, 79013.

*Corresponding author: natalya.koretska@gmail.com

https://doi.org/10.55251/jmbfs.4714

\section{ARTICLE INFO}

Received 27. 4. 2021

Revised 16. 8. 2021

Accepted 2. 9. 2021

Published 1. 2. 2022

Regular article open $\mathcal{O}$ access

\section{ABSTRACT}

Practically important metabolites of Rhodococcus erythropolis Au-1 strain were obtained: trehalose lipids, exopolysaccharide and cellular polymer - polyhydroxyalkanoate. The structures of the products were established by the methods of TLC, IR and UV-Vis spectroscopy. The purification of trehalose lipids from crude extract was carried out using silica gel column chromatography, one of the trehalose lipids fractions was identified as a trehalose dimycolate. The presence of $(\mathrm{NH})$ group was detected in the exopolysaccharide. For the first time, a biodegradable polymer was isolated from bacteria cells of the strain $R$. erythropolis Au-1, it was identified as the polyhydroxyalkanoate. The physico-chemical properties of the metabolites of the strain $R$. erythropolis Au-1 were established: the surface tension of trehalose lipids fractions was $30,5-43,2 \mathrm{mN} / \mathrm{m}$; the emulsification activity of the exopolysaccharide solutions (1-10 g/L) with vaseline oil was 42 $58 \%$. The differential thermal analysis was used to define starting temperatures of degradation of trehalose dimycolate (130 $\left.{ }^{\circ} \mathrm{C}\right)$, exopolysaccharide $\left(180^{\circ} \mathrm{C}\right)$ and polyhydroxyalkanoate $\left(164^{\circ} \mathrm{C}\right.$, melting point $\left.42 \mathrm{oC}\right)$. The obtained results expand the possibilities of practical application of trehalose lipids, exopolysaccharide and polyhydroxyalkanoate of the strain R. erythropolis Au-1.

Keywords: Rhodococcus erythropolis, trehalose lipids, exopolysaccharides, polyhydroxyalkanoates, thermal analysis, UV-Vis and IR spectroscopy

\section{INTRODUCTION}

The use of synthetic products is an acute problem due to their ecotoxicity and low biodegradability. Therefore, the successful development of modern technologies involves the introduction of new eco-friendly substances, which include biosurfactants and biopolymers of microbial origin (Fernandes et al, 2020; Johnson et al., 2020)

Actinobacteria of the genus Rhodococcus have practical potential, due to their ability to synthesize biosurfactants and biopolymers - exopolysaccharides (EPS) and cellular polyhydroxyalkanoates (PHA). Biosurfactants synthesized by Rhodococcus are glycolipids, specifically trehalose lipids (figure 1 a). These compounds combine high efficiency (foaming, emulsifying capacity, reduction of surface tension, solubilization, resilience to $\mathrm{pH}$ and temperature etc), biological activity and environmental safety. Generally they are less toxic and more biodegradable than synthetic surfactants (Jahan et al, 2020; Mulligan et al., 2014). The biosurfactants increase permeability of cell membranes, so enhance the effect of various biological active compounds (Sotirova $\boldsymbol{e t}$ al., 2012; Koretska $\boldsymbol{e}$ al., 2020; Yaremkevych et al., 2020). Therefore, much attention is paid to the use of biosurfactants in various industries, mainly in petroleum, food, cosmetics, pharmaceuticals, bioremediation and agriculture (Ceresa et al., 2021; Markande et al., 2021; da Silva et al., 2021).

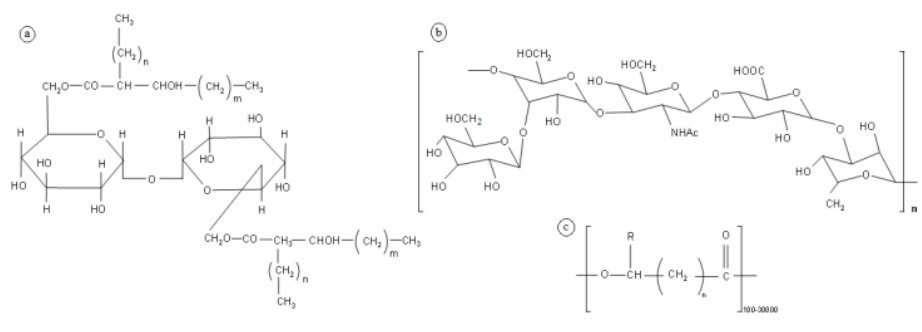

Figure 1 Structural formula of (a) trehalose-6,6'-dimycolate: $\mathrm{m}+\mathrm{n}=27-31$ (Rapp et al., 1979); (b) exopolysaccharide of $R$. erythropolis strain PR4: -Ac are fatty acids (Urai et al., 2007); (c) polyhydroxyalkanoate: $\mathrm{n}=1,2,3, \mathrm{R}-\mathrm{CH}_{3}, \mathrm{C}_{2} \mathrm{H}_{5}$, $\mathrm{C}_{3} \mathrm{H}_{7}, \mathrm{C}_{4} \mathrm{H}_{9}, \mathrm{C}_{5} \mathrm{H}_{11}, \mathrm{C}_{6} \mathrm{H}_{13}, \mathrm{C}_{7} \mathrm{H}_{15}, \mathrm{C}_{8} \mathrm{H}_{17}, \mathrm{C}_{9} \mathrm{H}_{19}, \mathrm{C}_{10} \mathrm{H}_{21}, \mathrm{C}_{11} \mathrm{H}_{23}, \mathrm{C}_{12} \mathrm{H}_{25}, \mathrm{C}_{13} \mathrm{H}_{27}$ (Ojumu et al., 2004).

Exopolysaccharides are high molecular weight extracellular polymers consisting of units of sugar moieties and can be attached to a carrier lipid, also be associated with proteins, lipids, metal ions etc. (Rana \& Upadhyay, 2020). At the same time exopolysaccharides of Rhodococcus erythropolis are composed of D-galactose, Dmannose, D-glucose and D-glucuronic and consist fatty acid residues (Urai $\boldsymbol{e t}$ al., 2007), figure $1 \mathrm{~b}$. microorganisms synthesize EPS to protect against extreme conditions in extreme conditions [Deming \& Young, 2017; Kazak et al., 2010] Exopolysaccharides have industrial applications in food, cosmetics, pharmaceutical, petroleum industries due to their properties, such as emulsifying, antioxidant, anti-biofilm, antiviral activities etc. (Madhuri \& Prabhakar, 2014; Rana \& Upadhyay, 2020).

Polyhydroxyalkanoates are natural polyesters accumulated in bacterial cells and served as both energy source and carbon storage, especially when bacteria grow on unbalanced media (Nisha et al., 2012; Sudesh et al., 2000). PHA consists of 100 - 30,000 monomeric units of 3-, 4-, 5 hydroxyalkanoic acids (Ojumu et al., 2004) (figure $1 \mathrm{c}$ ). Due to their biodegradability, biocompatibility, chemicaldiversity PHA are widely used in agriculture and medicine (Kalia et al., 2021; Zhang et al., 2018). PHA also are considered promising eco-friendly substitutes for plastics (Raza et al., 2018; Shah et al., 2008).

Thus, the aim of the present study is obtaining and investigation of metabolites of $R$. erythropolis Au-1 strain, promising for the replacement of synthetic materials.

\section{MATERIALS AND METHODS}

\section{Materials}

The objects of the study were the metabolites of the bacterial strain Rhodococcus erythropolis Au-1 (Ukrainian collection of microorganisms of D. Zabolotny 
Institute of Microbiology and Virology of the National Academy of Sciences of Ukraine (Rhodococcus erythropolis UCM Ac-603).

\section{Cultivation of $R$. erythropolis Au-1}

The cultivation of bacteria was performed in Erlenmeyer flasks $(750 \mathrm{ml})$ with a working volume $150 \mathrm{ml}$ on a rotary shaker $(220 \mathrm{rpm})$ at $30{ }^{\circ} \mathrm{C}$ in liquid nutrient medium with the following composition $(\mathrm{g} / \mathrm{L})$ : $\mathrm{NaNO}_{3}-3.0 ; \mathrm{K}_{2} \mathrm{HPO}_{4}-2.0$ $\mathrm{KH}_{2} \mathrm{PO}_{4}-2.0 ; \mathrm{MgSO}_{4} \times 7 \mathrm{H}_{2} \mathrm{O}-0.5 ; \mathrm{Na}_{3} \mathrm{C}_{6} \mathrm{H}_{5} \mathrm{O}_{7} \times 2 \mathrm{H}_{2} \mathrm{O}-1.0$; yeast extract -1.0 carbon source -20.0 ; distilled water - up to $1 \mathrm{~L}$ Cultivation time -5 days Hexadecane (for the biosynthesis of trehalose lipid surfactants) or glycerol (for the biosynthesis of PHA) were used as carbon sources. The inoculum (24h culture) was taken in the amount $10 \%$ of the medium's volume, the cell titer $-5 \times 10^{8}$ $\mathrm{CFU} / \mathrm{mL}$

\section{Isolation and purification of trehalose lipid surfactants}

The bacterial cells were separated from the cultural liquid by centrifugation at 6000 $\mathrm{rpm}$ for $15 \mathrm{~min}$. Trehalose lipids surfactants were extracted from cells with Folch mixture (chloroform-methanol 2:1) (Folch $\boldsymbol{e t}$ al., 1957). The trehalose lipids fractions were separated via chromatography method (Smyth et al., 2010) on a column of $220 \times 15 \mathrm{~mm}$ with silica gel 60 (0.06-0.20 mm, ROSS, Belgium). A sample of trehalose lipid surfactants $(0.1 \mathrm{~g})$ was dissolved in $15 \mathrm{~mL}$ of Folch mixture and was placed on a silica gel surface. The column was washed with hexane for removing of residual hexadecane, non-polar lipids and pigments. Next, the fractions were eluted with solvent systems with the gradually increasing polarity: chloroform, chloroform: methanol (90:10, 50:10, 40:10, 30:10, 20:10, 10:10), methanol. The composition of each fraction was monitored by thin layer chromatography method (TLC).

The plates "Merck" (25 Cromatofolhas AL TLC $20 \times 20 \mathrm{~cm}$ Silicagel 60 Germany) were used for TLC. Qualitative analysis was performed with a solven system - chloroform-methanol-water 65: 15: 2 . Identification of glycolipids as part of surfactants was performed by the plates visualization with 4-methoxy benzaldehyde spray reagent (Kretschmer \& Wagner, 1983; Smyth et al., 2010). The green spots on the plate indicated the glycolipids presence.

\section{Determination of physicochemical properties}

The surface tension of biosurfactants solutions was determined by Du Nui method with a platinum ring (Butt et al., 2003) on Krüss K6 tensiometer (Krüss GmbH, Germany). The emulsification activity was measured using the method described Rahman et al. (2003). About $2 \mathrm{~mL}$ of vaseline oil and $2 \mathrm{~mL}$ of cell-free medium (supernatant) were inoculated to a test tube and homogenized by vortexing at high speed for $2 \mathrm{~min}$. After $24 \mathrm{~h}$, the emulsification activity was determined as the percentage of height of the emulsified layer $(\mathrm{mm})$ divided by the total height of the liquid column (mm)

\section{Isolation and identification of polyhydroxyalkanoate}

Bacterial cells (after extraction of cell-bound biosurfactants) were disintegrated with ethanol $\left(100 \mathrm{rpm}, 2 \mathrm{~h}, 35^{\circ} \mathrm{C}\right)$. Centrifuged $(15 \mathrm{~min}, 6000 \mathrm{rpm})$, the precipitate was transferred to a Soxhlet extractor, where it was extracted with chloroform for 5 cycles of extraction. The solvent was evaporated in vacuum. The polymer was purified via dissolving in chloroform and precipitated with cold ethanol. The resulting polyhydroxyalkanoate precipitate was decanted and dried to constan weight (Semeniuk et al., 2020a, b). The preliminary identification of PHA was via TLC with a solvent system: ethyl acetate-benzene $1: 1$, visualization - in iodine chamber (5-10 min); the appearance of yellow-brown spots with $\mathrm{R}_{\mathrm{f}}=0.8$ indicated the PHA presence (Senthilkumar et al., 2016).

\section{Isolation of exopolysaccharide}

The exopolysaccharide was precipitated from the culture liquid supernatant (CLS) with two volumes of $96 \%$ ethanol and kept at $4{ }^{\circ} \mathrm{C}$ for $12 \mathrm{~h}$. (Williams \& Wimpenny, 1977). The precipitate was separated by centrifugation $(5000 \mathrm{rpm}, 30$ $\mathrm{min}$ ) and purified by reprecipitation from distilled water twice. The obtained EPS was dried at $80{ }^{\circ} \mathrm{C}$, the mass was determined gravimetrically.

\section{Infrared spectroscopy}

Infrared absorption spectra of the samples of trehalose-6,6'-dimycolate, exopolysaccharide, and polyhydroxyalkanoate, were analyzed on a Thermo Scientific Nicolet iZ10 Fourier spectrometer (USA) using diamond windows. The spectra were recorded in the wavenumber range within $4000-525 \mathrm{~cm}^{-1}$. The literature data (Gordon \& Ford, 1973) was used for spectrum interpretation.

\section{Ultraviolet - Visible Spectroscopy}

UV-Vis spectra was registered as described in (Panda et al., 2008). The purified and dried cellular polymer $(20 \mathrm{mg})$ was transferred into a test tube, and $10 \mathrm{ml}$ of concentrated $\mathrm{H}_{2} \mathrm{SO}_{4}$ was added. The solution was heated on a water bath for 10 minutes. After cooling and thorough agitation, the absorption spectrum of the obtained solution was registered. Concentrated $\mathrm{H}_{2} \mathrm{SO}_{4}$ was used as a solvent for comparison.

The absorption spectra of the samples in the UV-visible region were analyzed at $200-800 \mathrm{~nm}$ in quartz cuvettes $(1 \mathrm{~mm})$ on a UV mini-1240 spectrophotometer (Shimadzu, Japan).

\section{Thermal analysis}

Thermal analysis was performed on a Q-1500D derivatograph of the PaulikPaulik-Erdey system in the temperature range of $20-1000{ }^{\circ} \mathrm{C}$ with a free air access to the oven. The heating rate was $5^{\circ} \mathrm{C} / \mathrm{min}$. The average weight of the samples was $80 \mathrm{mg}$, the reference substance was aluminum oxide (Khovanets' et al., 2017).

\section{RESULTS AND DISCUSSION}

\section{Characteristics of trehalose-6,6-dimycolate}

Trehalose lipid surfactants were obtained via extraction from cells mass of the $R$ erythropolis Au-1 strain in the amount of $3.4 \mathrm{~g} \backslash \mathrm{L}$. These surfactants were found to contain non-polar lipids and polar lipids (Koretska et al., 2014; Kretschmer \& Wagner, 1983). Polar lipids have better surface activity, and trehalose lipids make up a significant mass fraction among them. The structure of trehalose- 6,6 ' dimycolate is shown in fig. 1 .

In order to isolate trehalose-6,6'-dimycolate, the extract of trehalose lipid surfactants of $R$. erythropolis Au- 1 strain was divided into fractions using the adsorption chromatography method on a column with silica gel (Figure 2).



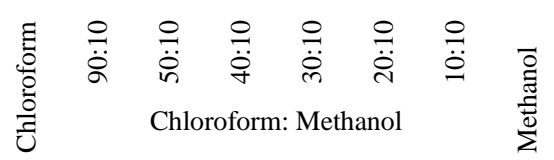

Figure 2 TLC of trehalose lipid surfactants fractions of $R$. erythropolis Au-1 strain solvent system - chloroform- methanol-water, 65:15:2, visualization with 4 methoxy-benzaldehyde.

The $\mathrm{R}_{\mathrm{f}}$ of obtained fractions and surface tension of their aqueous solutions $(0.5$ $\mathrm{g} / \mathrm{L}$ ) were determined (Table 1 ).

Table 1 Composition and characteristics of surfactant fractions of $R$. erythropolis Au-1

\begin{tabular}{|c|c|c|c|c|}
\hline $\begin{array}{l}\text { Fraction } \\
\text { № }\end{array}$ & Eluent & & $\begin{array}{l}\text { Surface } \\
\text { tension, } \\
\mathrm{mH} / \mathrm{m}\end{array}$ & $\mathbf{R}_{\mathbf{f}}$ \\
\hline 1 & Chloroform & & $52.0 \pm 0,4$ & $0.90 ; 0.78 ; 0.67$ \\
\hline 2 & \multirow{6}{*}{$\begin{array}{l}\text { Chloroform: } \\
\text { Methanol }\end{array}$} & $90: 10$ & $49.5 \pm 0,4$ & $0.90 ; 0.78 ; 0.67$ \\
\hline 3 & & $50: 10$ & $43.2 \pm 0,4$ & 0.50 \\
\hline 4 & & $40: 10$ & $37.5 \pm 0,5$ & $0.50 ; 0.30 ; 0.12$ \\
\hline 5 & & $30: 10$ & $32.0 \pm 0,5$ & $0.30 ; 0.14 ; 0.09$ \\
\hline 6 & & $20: 10$ & $31.7 \pm 0,4$ & $0.14 ; 0.09$ \\
\hline 7 & & $10: 10$ & $30.5 \pm 0,3$ & $0.14 ; 0.09$ \\
\hline 8 & Methanol & & 30.6 & $0.09 ; 0.04$ \\
\hline
\end{tabular}

Legend: surface tension was determined for lipid solutions $(0.5 \mathrm{~g} / \mathrm{L})$; mobile phase: chloroform- methanol- water, 65:15:2. 
It was found that fractions (№ 1, 2) contain nonpolar lipids (Kretschmer \& Wagner, 1983) and are characterized by insignificant surface activity (49.5-52.0 $\mathrm{mN} / \mathrm{m}$ ). In the fraction №3 the main component is trehaloso-6,6'-dimycolate, the surface tension of its solution is $43.2 \mathrm{mN} / \mathrm{m}$. Trehalose diacylates were detected in fractions № 4 and 5 (surface tension 32.0 - $37.5 \mathrm{mN} / \mathrm{m}$ ). Fractions $6-8$ contain trehalose monomycolates, trehalose monoacylates, lipopeptids and are characterized by lower surface tension: $30.5-31.7 \mathrm{mN} / \mathrm{m}$. Therefore, it was shown that the fractions of trehalose lipids are effective surfactants: the surface tension of their solutions was $30.5-43.2 \mathrm{mN} / \mathrm{m}$.

The fraction №3 (eluent chloroform: methanol 50:10) was identified by IR spectroscopy (Fig. 3 a). It was found the presence of the functional groups: 3500 $3200 \mathrm{~cm}^{-1}$ (hydrogen-bonded $(\mathrm{OH})$ groups); $2960-2800 \mathrm{~cm}^{-1}$ (stretching vibrations of $(\mathrm{CH})$ groups); $1200-1000 \mathrm{~cm}^{-1}$ (stretching vibrations of $(\mathrm{C}-\mathrm{O}-\mathrm{C})$ ether groups); a weak signal at $1700 \mathrm{~m}^{-1}$ may indicate a low content of $(\mathrm{C}=\mathrm{O})$ carbonyl groups.

The results obtained from the IR spectrum as well as TLC method $\left(R_{\mathrm{f}}=0.5\right)$ that reported in (Kretschmer \& Wagner, 1983) confirm that trehalose-6,6-dimycolate is produced.

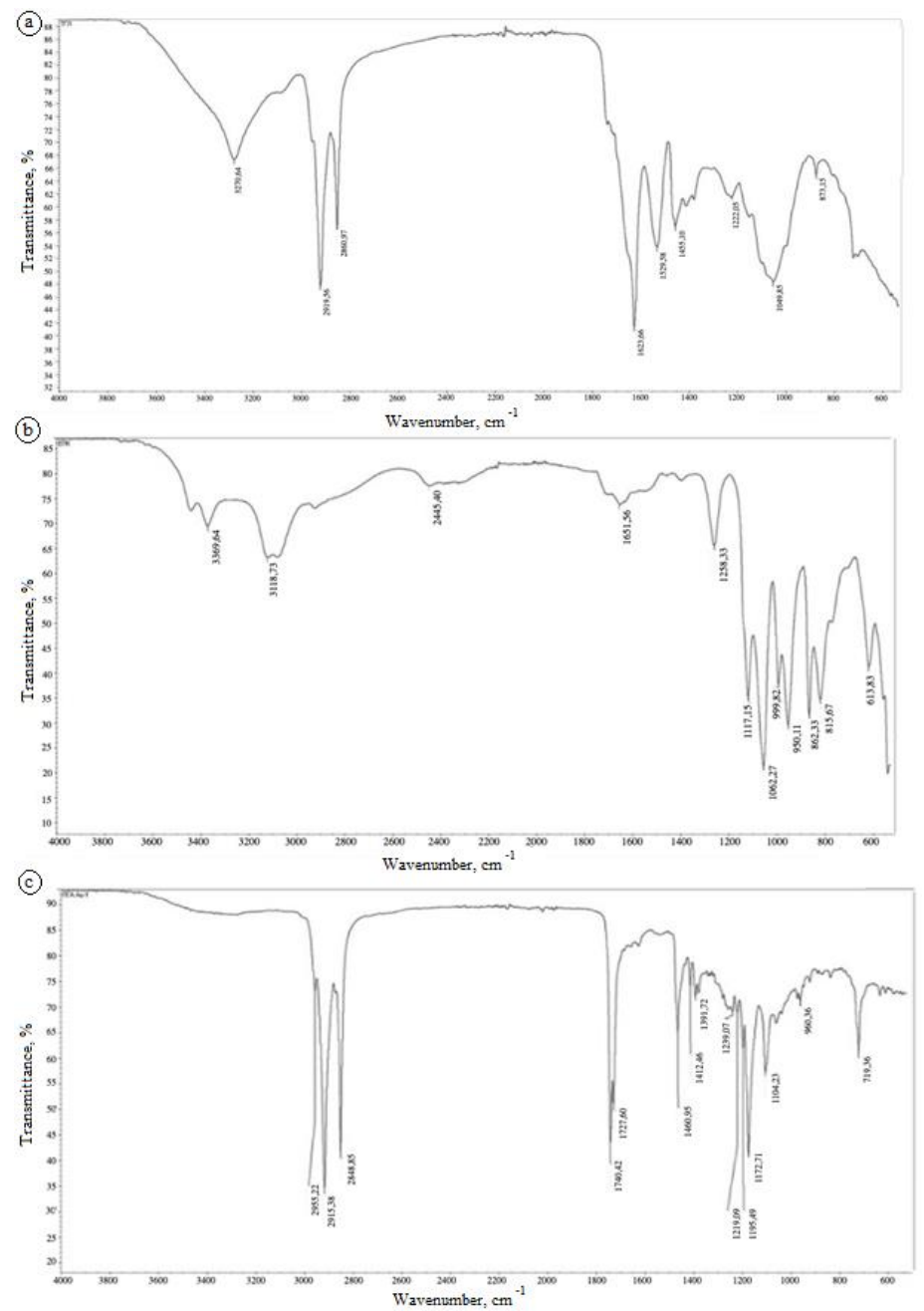

Figure 3 IR spectrums of metabolites of $R$. erythropolis Au-1: (a) trehalose-6,6'dimycolate (fraction № 3 of trehalose lipid surfactants), (b) exopolysaccharide, (c) the cellular biopolymer

\section{Characteristics of exopolysaccharide}

An extracellular polymer of polysaccharide nature was isolated from culture liquid supernatant of $R$. erythropolis Au-1 strain in the amount of $5.0 \mathrm{~g} \backslash \mathrm{L}$. The emulsifying activity of exopolysaccharide solutions with vaseline oil has been found. $\mathrm{E}_{24}$ of EPS solutions at $1 \mathrm{~g} / \mathrm{L}, 5 \mathrm{~g} / \mathrm{L}$, and $10 \mathrm{~g} / \mathrm{L}$ are $42 \%, 51 \%$, and $58 \%$, respectively. Thus, the extracellular polymer is an effective emulsifier. The exopolysaccharide of R. erythropolis Au-1 strain was identified by IR spectroscopy (Fig. 3 b). The EPS spectrum contains a band: at $3610 \mathrm{~cm}^{-1}$, which indicates stretching vibrations of the $(\mathrm{OH})$ group in the $\left(\mathrm{CH}_{2}-\mathrm{OH}\right)$ radical, the $3360 \mathrm{~cm}^{-1}$ band indicates such vibrations of the glucoside ring. In the spectrum, peaks of stretching vibrations of $(\mathrm{CH})$ groups are observed within $2900-2800 \mathrm{~cm}$ 1. A stretching vibration band of $(\mathrm{C}=\mathrm{O})$ carbonyl group is shown at $1700 \mathrm{~cm}^{-1}$. The $1117 \mathrm{~cm}^{-1}$ peak refers to stretching vibrations of $(\mathrm{C}-\mathrm{O}-\mathrm{C})$ ether group of a glycosidic bridge. The $1052 \mathrm{~cm}^{-1}$ band demonstrates stretching vibrations of $(\mathrm{C}-$
$\mathrm{O}-\mathrm{C}$ ) ether group of a glycosidic ring. Vibrations within $900-650 \mathrm{~cm}^{-1}$ point to stretching vibrations of $(\mathrm{NH})$ group. Data of the IR spectra of the R. erythropolis Au-1 exopolysaccharide are consistent with the results obtained by Urai $\boldsymbol{e t}$ al. (2007) for the exopolysaccharide of $R$. erythropolis PR4 strain (Fig. 1 b).

\section{Characteristics of polyhydroxyalkanoate}

For the first time, a light cream-colored biopolymer capable of forming a film was extracted from bacterial cells of the R. erythropolis Au-1. Its yield was $10 \%$ of the dry mass of cells. Fig. 4 shows the UV-Vis analysis of the sample of a cellular polymer after it is treated with $\mathrm{H}_{2} \mathrm{SO}_{4}$. This acid provides cleavage of PHA into crotonic acid with the absorption maximum at $235 \mathrm{~nm}$ (Panda et al., 2008).

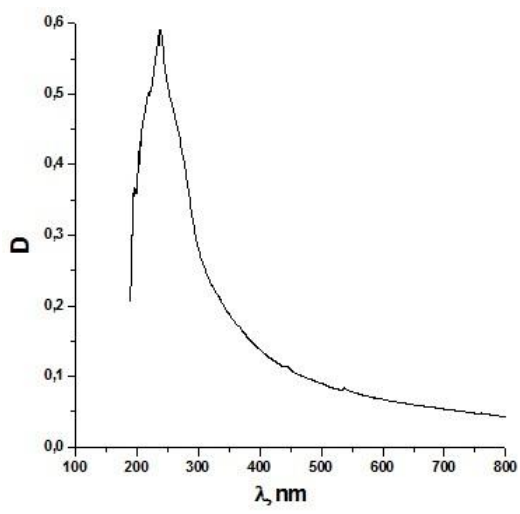

Figure $4 \mathrm{UV}$-Vis spectrum of the cellular biopolymer of $R$. erythropolis Au-1 strain.

The generated spectrum has a distinct peak at $235 \mathrm{~nm}$, which affords the resulting cellular polymer to be identified as polyhydroxyalkanoate.

The TLC method was used to confirm the nature of polyhydroxyalkanoate obtained, as shown in Fig. 5.



Figure 5 TLC of the cellular biopolymer of $R$. erythropolis Au-1 strain.

On the plate, which is visualized in the iodine chamber, it is possible to notice a yellow-brown spot $(\mathrm{Rf}=0.8)$, typical of PHA (Panda et al., 2008; Senthilkumar et al., 2016).

IR spectroscopy also was used to identify the cellular polymer of $R$. erythropolis Au-1 strain (Figure $3 \mathrm{c}$ ). It was shown the presence of following functional groups in IR spectrum: broad band at $3600-3100 \mathrm{~cm}^{-1}$ corresponds to stretching vibrations of $(\mathrm{OH})$ final groups; a set of bands at $2960-2800 \mathrm{~cm}^{-1}$ refers to the symmetric and asymmetric stretching vibrations of $(\mathrm{CH}),\left(\mathrm{CH}_{2}\right),\left(\mathrm{CH}_{3}\right)$ groups band at $1740 \mathrm{~cm}^{-1}$ points on stretching vibrations of $(\mathrm{C}=\mathrm{O})$ carbonyl group; band at $1238 \mathrm{~cm}^{-1}$ relates to the asymmetric stretching vibrations of ester groups $(\mathrm{C}-\mathrm{O}$ C); bands within $1463-1300 \mathrm{~cm}^{-1}$ correspond to bending vibrations of $\left(\mathrm{CH}_{2}\right)$ and $\left(\mathrm{CH}_{3}\right)$ groups

Thus, the methods TLC, the UV-Vis and IR spectroscopy confirmed the isolation of biopolymer-polyhydroxyalkanoate from the cells of $R$. erythropolis $\mathrm{Au}-1$ strain The structural formula of obtained PHA is consistent with the literature (Figure 1 c).

\section{Thermal analysis}

Thermal analysis is important method used to study organic and inorganic compounds. It is used to analyze thermal stability of substances as well as to obtain visualization of the nature of processes that proceed upon heating (Khovanets' et al., 2017). The results of the samples of obtained metabolites of $R$. erythropolis $\mathrm{Au}-1$ under investigation produced by the complex thermogravimetric, differential thermogravimetric, and differential thermal analyses are given as thermograms in the figure 6 

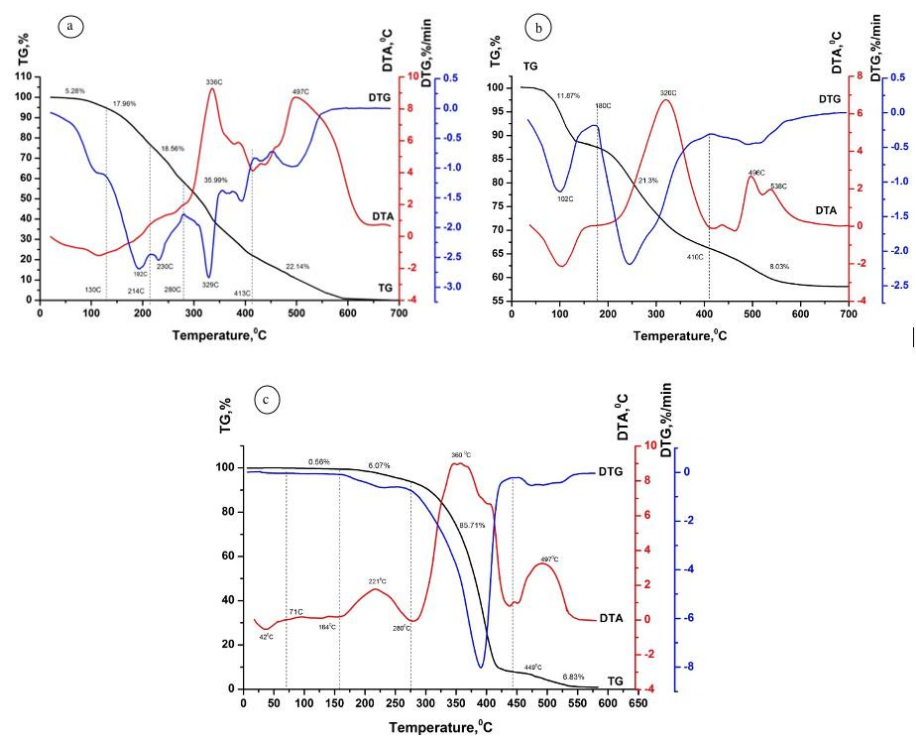

Figure 6 Thermogram of metabolites of $R$. erythropolis Au-1 strain: (a) trehalose6,6'-dimycolate, (b) exopolysaccharide, (c) the cellular biopolymer; TG thermogravimetric curve; DTA - differential thermal analysis curve; DTG differential thermogravimetric curve.

\section{Thermal analysis of trehalose dimycolate}

The thermal analysis shows that thermolysis of the sample of trehalose-6,6' dimycolate in the temperature range of $20-600{ }^{\circ} \mathrm{C}$ (Fig.6 a) proceed in five stages. In the temperature range of $20-130{ }^{\circ} \mathrm{C}$, the first stage features the emission of solvent residues. This is followed by the sample mass loss $-5.28 \%$ - on a thermogravimetric (TG) curve and the emergence of an endothermic effect on a differential thermal analysis (DTA) curve.

At the second and third stages of thermolysis, thermo-oxidative destruction of aliphatic fragments of the sample occurs in the temperature ranges of $130-214^{\circ} \mathrm{C}$ and $214-280^{\circ} \mathrm{C}$ with the formation of volatile decomposition products. This is accompanied by sharp extrema that appear on the DTG curve with the maximum at $192{ }^{\circ} \mathrm{C}$ and $230{ }^{\circ} \mathrm{C}$. It has been found the deviation of the DTA channel into the region of exothermic effects. The mass loss of the sample at the second and third stages of thermolysis is $17.96 \%$ and $18.56 \%$, respectively.

At the fourth stage of thermolysis, the sample undergoes deeper destructive processes in the temperature range of $280-413^{\circ} \mathrm{C}$. Such destructive processes are succeeded by the breakdown of fragments of a cyclic part of the molecule. The process ends up with partial combustion of residues of thermal-oxidative destruction of the aliphatic and cyclic parts of the trehalose-6,6'-dimycolate molecule. An intense mass loss of the sample such as $35.99 \%$ is accompanied by a sharp extremum on the DTG curve with the maximum at $329^{\circ} \mathrm{C}$ and an extremely notable exothermic effect on the DTA curve with the maximum at $336{ }^{\circ} \mathrm{C}$.

In the temperature range of $413{ }^{\circ} \mathrm{C}-650{ }^{\circ} \mathrm{C}$, there is combustion of carbonized residue of the sample formed at the previous stages of thermolysis. Following this, one can observe the mass loss of the sample $\left(22.14^{\circ} \mathrm{C}\right)$ and the sharp extremum on the DTA curve with the maximum at $497^{\circ} \mathrm{C}$

\section{Thermal analysis of exopolysaccharide}

Thermal degradation of the sample of exopolysaccharide of $R$. erythropolis Au-1 strain proceeds in three stages in the temperature range of $20-700{ }^{\circ} \mathrm{C}$ (Fig. 6 b) At the first stage of thermolysis, the emission of physically bound water happens in the temperature range of $20-180{ }^{\circ} \mathrm{C}$. After the emission, it is possible to observe the sample mass loss $(11.87 \%)$, the distinct extremum on the DTG curve, and the endothermic effect on the DTA curve with the maximum at $103^{\circ} \mathrm{C}$. At the second stage of thermolysis, there is thermal-oxidative destruction of EPS in the temperature range of $180-410^{\circ} \mathrm{C}$, which is followed by a gradual mass loss $(21.3$ $\%$ ) of the sample and a sharply expressed exothermic effect on the DTA curve with the maximum at $320{ }^{\circ} \mathrm{C}$. At the third stage of thermolysis, carbonized residue of the sample is gradually combusted. This process is in accord with a double exothermic effect noticed on the DTA curve with the maximum at temperatures $496{ }^{\circ} \mathrm{C}$ and $598{ }^{\circ} \mathrm{C}$. The mass loss at this stage accounts for $8.03 \%$.

\section{Thermal analysis of polyhydroxyalkanoate}

Thermal degradation of the PHA sample of the $R$. erythropolis Au-1 strain includes five stages (Fig. $6 \mathrm{c}$ ). At the first stage of thermolysis, the biopolymer sample melts at $20-71^{\circ} \mathrm{C}$. There is no loss of sample weight during this process. The process proceeds with a distinct endothermic effect, which manifests itself on the DTA curve with a maximum at $42{ }^{\circ} \mathrm{C}$. At the second stage of thermolysis, a slight mass loss of the sample at the temperature range of $71-164{ }^{\circ} \mathrm{C}$ might be because of the emission of volatile substances present in the sample. This process is accompanied by a slight mass loss of the sample, such as $0.56 \%$. At the temperatures 164 $280{ }^{\circ} \mathrm{C}$, at the third stage of thermolysis, a more intense mass loss of the sample $(6.07 \%)$ corresponds to the conduct of thermal oxidative processes in biopolymers This can be seen by a distinct exothermic effect that is manifested on the DTA curve with the temperature maximum at $221{ }^{\circ} \mathrm{C}$. Deep destructive processes, which are completed with combustion of destruction residues, happen at the temperatures $280-449^{\circ} \mathrm{C}$ at the fourth stage of thermolysis. Such processes are followed by an $85.71 \%$ rapid mass loss of the sample and occurrence of a high exothermic effect on the DTA curve with the maximum at $360{ }^{\circ} \mathrm{C}$. Combustion of carbonized residue of the biopolymer takes place in the temperature range of $449-600{ }^{\circ} \mathrm{C}$ at the fifth stage of thermolysis - it is observed the exothermic effect with maxima at $497{ }^{\circ} \mathrm{C}$ on the DTA curve.

\section{CONCLUSIONS}

Trehalose lipids $(3.4 \mathrm{~g} / \mathrm{L})$, exopolysaccharide $(5.0 \mathrm{~g} / \mathrm{L})$ and cellular polymer polyhydroxyalkanoate (10\% of the dry mass of cells) of actinobacteria $R$. erythropolis $\mathrm{Au}-1$ strain were obtained.

The definition of products' structures was carried out using the TLC method, the IR and UV-Vis spectroscopy. It was shown that the cellular polymer belongs to polyhydroxyalkanoates; there are $(\mathrm{NH})$ groups in the structure of the exopolysaccharide; one of the biosurfactants' fractions was identified as trehalose dimycolate. It was found that the surface tension of trehalose lipids fractions was $30,5-43,2 \mathrm{mN} / \mathrm{m}$; the emulsification activity of the exopolysaccharide solutions (1$10 \mathrm{~g} / \mathrm{L}$ ) with vaseline oil was $42-58 \%$. Due to differential thermal analysis, starting temperatures of degradation of trehalose dimycolate $\left(130^{\circ} \mathrm{C}\right)$, exopolysaccharide $\left(180{ }^{\circ} \mathrm{C}\right)$ and polyhydroxyalkanoate $\left(164{ }^{\circ} \mathrm{C}\right)$ were defined. The melting point of polyhydroxyalkanoate was obtained $\left(42^{\circ} \mathrm{C}\right)$.

Thus, the possibility of maximum use of the components of the culture fluid of the strain R. erythropolis Au-: both cells and supernatant is shown. This approach is economically and environmentally justified. The study of physico-chemical properties of the obtained products shows that in practice they can replace synthetic surfactants, emulsifiers and polymeric materials.

Acknowledgment: The authors would like to thank Dr. Taisiya Nogina (Department of Physiology of industrial microorganisms, Danylo Zabolotny Institute of Microbiology and Virology, National Academy of Sciences of Ukraine) for the provided $R$. erythropolis Au-1 strain and Mr. Yaroslav Kovalskyi (Department of Physical and Colloid Chemistry, Ivan Franko National University of Lviv) for the interpretation of infrared spectra.

\section{REFERENCES}

Butt, H. J., Graf, K., \& Kappl, M. (2013). Physics and chemistry of interfaces. John Wiley \& Sons.

Ceresa, C., Fracchia, L., Fedeli, E., Porta, C., \& Banat, I. M. (2021). Recent Advances in Biomedical, Therapeutic and Pharmaceutical Applications of Microbial Surfactants. Pharmaceutics, 13(4), https://doi.org/10.3390/pharmaceutics13040466

Deming, J. W., \& Young, J. N. (2017). The role of exopolysaccharides in microbial adaptation to cold habitats. In Psychrophiles: from biodiversity to biotechnology (pp. 259-284). Springer, Cham. https://doi.org/10.1007/978-3319-57057-0_12

Fernandes, M., Alves, M., \& Vicente, A. A. (2020). Factors affecting polyhydroxyalkanoates biodegradation in soil. Polymer Degradation and Stability, 109408. https://doi.org/10.1016/j.polymdegradstab.2020.109408

Folch, J., Lees, M., \& Stanley, G. S. (1957). A simple method for the isolation and purification of total lipides from animal tissues. Journal of biological chemistry, 226(1), 497-509. https://www.ncbi.nlm.nih.gov/pubmed/13428781

Gordon, A. \& Ford, R. (1973). The Chemist's Companion: A Handbook of Practical Data, Techniques, and References 1st Edition. Arnold J. Gordon, Richard A. Ford. Willey. P.560.

Jahan, R., Bodratti, A. M., Tsianou, M., \& Alexandridis, P. (2020). Biosurfactants, natural alternatives to synthetic surfactants: physicochemical properties and applications. Advances in colloid and interface science, 275, 102061. https://doi.org/10.1016/j.cis.2019.102061

Johnson, P., Pinfield, V. J., Starov, V., \& Trybala, A. (2020). Effect of synthetic surfactants on the environment and the potential for substitution by biosurfactants. Advances in Colloid and Interface Science, 102340 https://doi.org/10.1016/j.cis.2020.102340

Kalia, V. C., Patel, S. K. S., Shanmugam, R., \& Lee, J. K. (2021) Polyhydroxyalkanoates: trends and advances toward biotechnological applications. Bioresource Technology, 124737. https://doi.org/10.1016/j.biortech.2021.124737 
Kazak, H., Oner, E. T., \& Dekker, R. F. (2010). Extremophiles as sources of exopolysaccharides. Carbohydrate Polymers: Development, Properties and Applications, 605-619.

Khovanets, G., Makido, O., Kochubei, V., Sezonenko, T., Medvedevskikh, Y., \& Voloshynets, V. (2017). Thermal Stability of Organic-Inorganic Composites Based on Dimethacrylate-Tetraethoxysilane System. Chemistry \& Chemical Technology, 11 (2), 158-165. https://doi.org/10.23939/chcht11.02.158

Koretska, N., Prystai, M., \& Karpenko, O. (2014). Rape phosphatide concentrate in the technologies of surfactants production by the Actinobacteria. Ukrainian food journal, 3 (3), 429-436.

Koretska, N., Karpenko, I., Karpenko, O., Baranov, V., \& Midyana, H. (2020). Trehalose lipid and rhamnolipid surfactants as plant growth regulators. Journal of microbiology, biotechnology and food sciences, 10(3), 405-408. https://doi.org/10.15414/jmbfs.2020.10.3.405-408

Kretschmer A, Wagner F. (1983). Characterization of biosynthetic intermediates of trehalose dicorynomycolates from Rhodococcus erythropolis grown on nalkanes. Biochimica et Biophysica Acta.,753, 306-313. https://doi.org/10.1016/0005-2760(83)90053-X

Madhuri, K. V. \& Prabhakar, K. V. (2014). Microbial exopolysaccharides: biosynthesis and potential applications. Oriental journal of chemistry, 30(3), 1401 http://dx.doi.org/10.13005/ojc/300362

Markande, A. R., Patel, D., \& Varjani, S. (2021). A review on biosurfactants: properties, applications and current developments. Bioresource Technology, 124963. https://doi.org/10.1016/j.biortech.2021.124963

Mulligan, C. N., Sharma, S. K., Mudhoo, A., \& Makhijani, K. (2014). 1 Green Chemistry and. Biosurfactants: Research trends and applications, 1. Boca Raton: CRC Press, Taylor\&Francis Group; p. 323 https://www.academia.edu/15914943/BIOSURFACTANTS Research Trends a nd Applications

Nisha, J., Mudaliar, N., Senthilkumar, P., \& Samrot, A. V. (2012). Influence of substrate concentration in accumulation pattern of poly (R) hydroxyalkonoate in Pseudomonas putida SU-8. African Journal of Microbiology Research, 6(15), 3623-3630. https://doi.org/10.5897/AJMR11.1509

Ojumu, T. V., Yu, J., \& Solomon, B. O. (2004). Production of polyhydroxyalkanoates, a bacterial biodegradable polymers. African journal of Biotechnology, 3(1), 18-24.. https://doi.org/10.5897/AJB2004.000-2004

Panda B, Sharma L, Singh A, Mallick N. Thin layer chromatographic detection of poly- $\beta$-hydroxybutyrate (PHB) and poly- $\beta$-hydroxyvalerate (PHV) in cyanobacteria. Indian Journal of Biotechnology. 2008; 7(2):230-234. http://nopr.niscair.res.in/handle/123456789/1833

Rahman, K. S. M., Rahman, T. J., Lakshmanaperumalsamy, P., Marchant, R., \& Banat, I. M. (2003). The potential of bacterial isolates for emulsification with a range of hydrocarbons. Acta biotechnologica, 23(4), 335-345. https://doi.org/10.1002/abio.200390043

Rana, S., \& Upadhyay, L. S. B. (2020). Microbial exopolysaccharides: Synthesis pathways, types and their commercial applications. International journal of biological macromolecules, 157

https://doi.org/10.1016/j.ijbiomac.2020.04.084

Rapp, P., Bock, H., Wray, V., \& Wagner, F. (1979). Formation, isolation and characterization of trehalose dimycolates from Rhodococcus erythropolis grown on n-alkanes. Microbiology, 115(2), 491-503. https://doi.org/10.1099/00221287$\underline{115-2-491}$

Raza, Z. A., Abid, S., \& Banat, I. M. (2018). Polyhydroxyalkanoates: Characteristics, production, recent developments and applications. International Biodeterioration \& Biodegradation, 126, 45-56. https://doi.org/10.1016/j.ibiod.2017.10.001

Semeniuk, I., Kochubei, V., Skorokhoda, V., Pokynbroda, T., Midyana, H., Karpenko, E., \& Melnyk, V. (2020). Biosynthesis Products of Pseudomonas sp. PS-17 Strain Metabolites. 1. Obtaining and Thermal Characteristics. Chemistry \& Chemical Technology, 1 (14), 2020, (1), 26-31. https://doi.org/10.23939/chcht14.01.026.

Semeniuk I, Pokynbroda T, Kochubei V, Midyana H, Karpenko O, Skorokhoda V. (2020). Biosynthesis and characteristics of polyhydroxyalkanoates. 1. Polyhydroxybutyrates of Azotobacter vinelandii N-15. Chem. Chem. Technol., 14 (4): 463-467. https://doi.org/10.23939/chcht14.04.

Senthilkumar P, Dawn SS, Samrot AV, Kumar N. (2016). Production, Optimization and Characterization of Poly [R] Hydroxyalkanoate from Enterobacter sp SU16. Indian Journal of Science and Technology., 9 (45). https://doi.org/10.17485/ijst/2016/v9i45/87822

Shah A, Hasan F, Hameed A, Ahmed S. (2008). Biological degradation of plastics: a comprehensive review. Biotechnology advances., 26: 246-65. https://doi.org/10.1016/j.biotechadv.2007.12.005

da Silva, I. F., Neves, N. A., e Silveira, B. M. P., Vespermann, K. A. C., \& Valente, M. E. R. (2021). Microbial Biosurfactants for Contamination of Food Processing. Microbial Biosurfactants, 11-30. https://doi.org/10.1007/978-98115-6607-3_2

Smyth, T., Perfumo, A., Marchant, R., \& Banat, I. (2010). Isolation and Analysis of Low Molecular Weight Microbial Glycolipids. In Handbook of Hydrocarbon and Lipid Microbiology. pp. 3705-3723. Springer.
https://link.springer.com/referenceworkentry/10.1007\%2F978-3-540-775874_291

Sotirova, A., Avramova, T., Stoitsova, S., Lazarkevich, I., Lubenets, V., Karpenko, E., \& Galabova, D. (2012). The importance of rhamnolipid-biosurfactant-induced changes in bacterial membrane lipids of Bacillus subtilis for the antimicrobial activity of thiosulfonates. Current microbiology, 65(5), 534-541. https://link.springer.com/article/10.1007/s00284-012-0191-7

Sudesh K, Abe H, Doi Y. (2000). Synthesis, structure and properties of polyhydroxyalkanoates: biological polyesters. Prog. Polym. Sci. , 25(10), 15031555. https://doi.org/10.1016/S0079-6700(00)00035-6

Urai, M., Yoshizaki, H., Anzai, H., Ogihara, J., Iwabuchi, N., Harayama, S., ... \& Nakajima, M. (2007). Structural analysis of mucoidan, an acidic extracellular polysaccharide produced by a pristane-assimilating marine bacterium, Rhodococcus erythropolis PR4. Carbohydrate research, 342(7), 927-932. https://doi.org/10.1016/j.carres.2007.02.002

Williams AG, Wimpenny YW. (1977). Exopolysaccharide production by Pseudomonas NCIB 11264 grown in bat culture. Journal of Biological Chemistry., 102 (1), 12 - 21. https://doi.org/10.1099/00221287-102-1-13

Yaremkevych, O., Fihurka, O., Banya, A., Shvets, V., Nakonechna, A., Karpenko, O., ... \& Lubenets, V. (2020). Effect of thiosulfonate-biosurfactant compositions on plants grown in oil polluted soil. Environmental Engineering \& Management Journal (EEMJ), 19(11).

Zhang, J., Shishatskaya, E. I., Volova, T. G., da Silva, L. F., \& Chen, G. Q. (2018). Polyhydroxyalkanoates (PHA) for therapeutic applications. Materials Science and Engineering: C, 86, 144-150. https://doi.org/10.1016/j.msec.2017.12.035 